\title{
JOANNA KANTOR-MARTYNUSKA
}

\author{
Miarka Zdrowia, Warszawa \\ e-mail:miarka@miarkazdrowia.pl

\section{Psychologia muzyki w nauce i praktyce. Wspomnienie o Profesor Marii Manturzewskiej*}

\section{WPROWADZENIE}

Pod koniec 2020 roku pożegnaliśmy prof. Marię Manturzewską - psycholog, prekursorkę psychologii muzyki (a zwłaszcza psychologii muzyków) w Polsce. Studiowała psychologię pod kierunkiem prof. Stefana Szumana, filozofię u prof. Romana Ingardena i antropologię u prof. Kazimierza Stołyhwy. Uczyła się gry na fortepianie. Już od czasu studiów przejawiała wielorakie zainteresowania i zamiłowanie do poruszania tematów z pogranicza różnych dziedzin wiedzy. Interdyscyplinarność była jej znakiem rozpoznawczym. Łączyła dziedziny, łączyła ludzi. We wczesnym okresie swej pracy naukowej interesowała się zarówno odbiorem emocjonalnego wyrazu muzyki, jak i antropometrią. Przez większość życia zgłębiała rolę czynników biograficznych i osobowościowych $\mathrm{w}$ powodzeniu w zawodzie muzyka. Interesował ją talent - jego pomiar, prognozowanie i wspieranie. Przyjmowała szeroką definicję uzdolnienia muzycznego obejmującego aspekt sensoryczny, intelektualny, emocjonalno-motywacyjny i kinestetyczno-motoryczny. Tak rozumiane uzdolnienie wyznacza według niej stosunek człowieka do muzyki i efektywność działań podejmowanych w tej dziedzinie. Prowadziła badania psychologiczne w odniesieniu do osób o wybitnych uzdolnieniach i osiagnię- ciach muzycznych. W studiach nad życiorysami muzyków dociekała, czym jest i jak powstaje talent wykonawczy, który stanowi o kunszcie muzyka. Marię Manturzewską interesował także odbiór emocjonalnych walorów muzyki przez słuchaczy. Widziała potrzebę wspierania muzyków mających trudności związane z występowaniem na scenie. Angażowała się w budowanie podstaw poradnictwa psychologicznego dla uczniów szkół muzycznych. Podkreślała, że wyniki badań naukowych powinny być podstawą dla terapeutów. Poradnictwo psychologiczne dla muzyków, które z czasem zostało w Polsce szeroko rozpowszechnione, nie miało sobie równych za granica.

Działalność naukowa Marii Manturzewskiej w środowisku muzyków i pedagogów muzyki zasługuje na utrwalenie i refleksję. Można też z niej wyciągnąć wnioski na przyszłość dla psychologów, muzyków, pedagogów muzyki oraz dzieci i młodzieży, uczestniczących w edukacji muzycznej. Niniejszy artykuł powstał na podstawie rozmów z osobami, które z profesor Manturzewską współpracowały, zetknęły się bezpośrednio lub inspirowały jej działalnością naukową - dr Jolantą Kępińską-Welbel, dr. Kacprem Miklaszewskim, dr. Andrzejem Białkowskim, dr Marią Chełkowską-Zacharewicz i mgr. Mateuszem Migutem. Ze wspomnień tych wyłania się obraz osoby o niespożytej energii, sta-

* Autorka dziękuje dr Jolancie Kępińskiej-Welbel, dr. Kacprowi Miklaszewskiemu, dr. Andrzejowi Białkowskiemu, dr Marii Chełkowskiej-Zacharewicz i mgr. Mateuszowi Migutowi za przekazanie informacji, które umożliwiły powstanie tekstu. Podziękowanie obejmuje także uwagi pomocne w opracowaniu jego ostatecznej wersji. 
wiającej wyzwania intelektualne swojemu środowisku. Refleksja nad rozłożeniem akcentów w zainteresowaniach profesor Manturzewskiej i jej wyborem problemów badawczych skłania do rewizji sposobu myślenia o edukacji muzycznej w Polsce. Praca w tym zakresie wydaje się słuszną kontynuacją wysiłku, który Maria Manturzewska wkładała w swą pracę przez kilkadziesiąt lat.

\section{PUNKT WYJŚCIA. BADACZKA I PROMOTORKA}

Emanowała zapałem i entuzjazmem. Patrzyła, jakby umiała przejrzeć człowieka na wylot. Potrafiła zobaczyć w nieopierzonym magistrancie jego przyszłe naukowe dokonania. Mówiła szybko, czasem lekko się jąkając, być może z powodu nadmiaru tego, co miała do powiedzenia. Studentom zalecała, aby znali trzy języki obce i czytali literaturę naukową w oryginale. Tak jak ona. Zachęcała do udziału w konferencjach, rozwijania międzynarodowych kontaktów, dyskutowania o wynikach najnowszych badań. Jak ona.

W 1974 roku w Akademii Muzycznej w Warszawie powstał Instytut Pedagogiki Muzycznej, a w nim Zakład (później Katedra) Psychologii Muzyki. Założono także Poradnię dla Muzyków, która współpracowała z Poradnią Zdrowia Psychicznego. Szefem Instytutu był dr Wojciech Jankowski, a jego współtwórczynią - Maria Manturzewska. Instytut miał status międzyuczelniany. Odbywały się w nim cotygodniowe zebrania naukowe. Tworzono interdyscyplinarny zespół podejmujący zagadnienia badawcze $\mathrm{z}$ zastosowaniem metod zaczerpniętych z psychologii i pedagogiki. Wszyscy wiedzieli, czym zajmują się pozostali członkowie zespołu. Praca przebiegała w miłej atmosferze, choć uwarunkowania zewnętrzne nie były sprzyjające. Brakowało funduszy, a stopniowo również zrozumienia dla roli badań z zakresu pedagogiki i psychologii muzyki. W 1992 Instytut Pedagogiki Muzycznej zamknięto, a Katedrę Psychologii Muzyki przekształcono w Międzywydziałową Katedrę Psychologii Muzyki, której Maria Manturzew- ska została kierowniczką. Pracownia mieściła się w jednym pokoju.

W Instytucie Pedagogiki Muzycznej Katedra Psychologii zajmowała się psychologicznymi podstawami działalności muzycznej, w tym pedagogiki (na przykład problematyką uczenia się muzyki). Maria Manturzewska stawiała sobie wówczas za cel nie tylko prowadzenie badań, ale także upowszechnianie wiedzy psychologicznej w środowisku muzyków i nauczycieli muzyki. System kształcenia, koncepcje pedagogiczne i metodyka wychowania muzycznego były domeną Katedry Pedagogiki kierowanej przez dr. Wojciecha Jankowskiego. Katedra Psychologii sprowadzała i adaptowała do warunków polskich między innymi testy zdolności i osiągnięć muzycznych. Katedra Pedagogiki prowadziła prace adaptacyjne nad koncepcjami Emila Jacques'a-Dalcroze'a, Zoltana Kodalya i Edwina E. Gordona, organizowała seminaria itd. Czasem wątki psychologiczne i pedagogiczne się splatały. Dr Kacper Miklaszewski - wieloletni współpracownik Marii Manturzewskiej opublikował artykuły o programie wychowania muzycznego w USA i kształceniu nauczycieli muzyki w tym kraju, przybliżając czytelnikom system edukacji muzycznej odmienny od polskiego. Prof. Barbara Kamińska prowadziła prace badawcze z pogranicza psychologii i pedagogiki, których podsumowanie stanowi książka Kompetencje wokalne dzieci i młodzieży - ich poziom, rozwój i uwarunkowania (1997).

Dr Jolanta Kępińska-Welbel, psycholog kliniczna, długoletnia członkini zespołu Katedry Psychologii Muzyki, jako jedna z pierwszych wspierała muzyków w radzeniu sobie $\mathrm{z}$ trema. Z uwagi na wykształcenie muzyczne i psychologiczne oraz doświadczenie kliniczne była przygotowana do pracy z muzykami nad ich trudnościami dotyczącymi występowania na scenie. Przez pierwszy rok w ramach wolontariatu w poradni dla muzyków prowadziła z nimi wywiady. Sprawdziła się w tej roli i w 1978 roku zaproponowano jej stałą pracę.

Maria Manturzewska jako szefowa była osobą otwartą, ale i niełatwą w kontakcie. Wobec osób spoza zespołu utrzymywała dystans i sprawiała wrażenie nieprzystępnej. Umówienie się $\mathrm{z}$ nią stanowiło nie lada wyzwanie. Szanowano 
ją. Była ponad konfliktami i można było mieć do niej zaufanie, którego nigdy nie zawiodła. Nie miała żalu o spieranie się z nią na tematy naukowe. Pozwalała się ze sobą kłócić. Mimo bezpośredniej i swobodnej komunikacji w Katedrze wiele osób nie wytrzymywało oczekiwań i tempa pracy. Maria Manturzewska miała wiele pomysłów badawczych, ale nie zawsze przywiązywała wagę do ograniczeń kadrowych i materialnych uczelni. Jako pasjonatka niekiedy stawiała cele naukowe ponad realiami koniecznymi do ich realizacji.

W Katedrze pracownicy młodsi stażem otrzymywali wsparcie w planowaniu i prowadzeniu pracy badawczej. Wśród muzyków brakowało osób z wykształceniem psychologicznym, a tylko niektórzy psychologowie i pedagodzy mieli wyższe wykształcenie muzyczne. Wzajemnie się uzupełniano i dokształcano. Maria Manturzewska wymagała udziału w regularnych szkoleniach z zakresu teorii testów psychologicznych, psychologii rozwojowej, statystyki, metodologii badań. Autorytetem wśród muzyków był przyjaciel i opiekun zespołu, prof. Tadeusz Wroński, a wątki psychologiczne przez kilka lat regularnie konsultował prof. Tadeusz Tomaszewski. Do częstych gości Katedry należeli profesorowie Andrzej Strzałecki, Jan Strelau i Janusz Kostrzewski. Pracownicy Katedry konsultowali się także u profesorów Anny i Zbigniewa Brzezińskich oraz Edwarda Nęcki i czynnie uczestniczyli w zjazdach PTP. Ponieważ jednak badania prowadzone z udziałem wyłącznie muzyków pozwalały na wyciaganie wniosków tylko wobec tej wyspecjalizowanej grupy, brakowało głębszej integracji naukowej ze środowiskiem akademickim spoza kręgów muzycznych. Skutkowało to pewnym wyobcowaniem zespołu w środowisku psychologów.

W Akademii Muzycznej muzycy nieufnie traktowali dziedzinę pedagogiki muzycznej, która podkreślała wagę metodyki. Trzeba było jednak przemycać ją przyszłym nauczycielom gry na instrumencie. Studenci Akademii Muzycznej mieli zajęcia z psychologii i pedagogiki. Ponieważ muzycy przejawiali ambicje pracy naukowej, potrzebne były standardy metodologiczne, które ich prace powinny spełniać. Psychologia takich ram dostarczała. Maria Mantu- rzewska ubolewała, że z kolei psychologowie praktycy rzadko mają kompetencje muzyczne, które pozwalałyby im rozumieć muzyków. Brakowało studentów psychologii mających pojęcie o muzyce. Manturzewska prowadziła więc na Wydziale Psychologii Uniwersytetu Warszawskiego kursy z zakresu psychologii muzyki. Mgr Mateusz Migut, psycholog, jako doktorant uczestniczył w seminariach Międzywydziałowej Katedry Psychologii Muzyki (wtedy już na Uniwersytecie Muzycznym) w ostatnich latach jej funkcjonowania. Prowadził również wykłady fakultatywne z psychologii muzyki na Uniwersytecie Warszawskim. Prof. Manturzewska bywała ich gościem. Ciepłym słowem wspierała te działania.

Profesor Maria Manturzewska miała dar intuicji naukowej. Czuła ważne problemy środowiska muzycznego. Przewidywała wyniki badań. Nauka miała być żywa, nie laboratoryjna. Miała służyć muzykom. Filarem renomy prof. Manturzewskiej w dziedzinie psychologii muzyki stały się badania uczestników konkursów chopinowskich - projekt śmiały i szeroko zakrojony, lecz nierozwijany. Badania te miały swoje znaczenie w odniesieniu do szczególnej grupy - uczestników konkursów chopinowskich. Dostarczały cennych informacji o ich rozwoju artystycznym i jego kontekście środowiskowym. Stanowiły wstęp do późniejszych badań biograficznych. Nie były jednak kontynuowane, a ich wyniki w formie publikacji książkowej Psychologiczne warunki osiagnięć pianistycznych $\mathrm{w} 1969$ roku dotarły głównie do czytelników polskojęzycznych. Rezultaty rozbudowanych badań biograficznych oraz oparty na nich model rozwoju artystyczno-zawodowego muzyków w ciagu życia opublikowano w czasopiśmie „Psychology of Music" (1990). Wnioski przekazano szerokiej grupie odbiorców anglojęzycznych. Publikacje te przyczyniły się do rozwoju wiedzy na temat osobowościowych i biograficznych uwarunkowań wybitnych osiagnięć w dziedzinie wykonawstwa muzycznego.

Maria Manturzewska wysoko ceniła trafność ekologiczną badań naukowych. Nieustrukturyzowane wywiady z muzykami prowadzone w konkursowych kuluarach kontrastowały pod 
tym względem ze sterylnym schematem badania naukowego, praktykowanym przez badaczy uniwersyteckich. Taki styl uprawiania nauki przez profesor Manturzewską nie przekonywał empiryków, którzy wówczas skrupulatnie realizowali planowane eksperymenty w laboratoriach. Ona zaś takie właśnie badania traktowała $\mathrm{z}$ rezerwą. Według niej ze względu na szacunek dla paradygmatu ich walor ekologiczny schodził na dalszy plan, co dotyczyło również możliwości wyciagania wniosków dla praktyków.

Maria Manturzewska była rzeczniczką nurtu humanistycznego w psychologii. Część programu Katedry stanowiły badania dotyczące uczenia się muzyki, zapoczątkowane przez pozyskiwanie danych samoopisowych od muzyków pracujących nad nowymi utworami. Maria Manturzewska jako pierwsza w Polsce wprowadziła testy zdolności muzycznych. Na początku pracowała w Polskiej Akademii Nauk w Pracowni Metod Diagnozy Psychologicznej, której szefował Mieczysław Chojnowski. W psychologii od lat 60. XX wieku testy zdolności, podobnie jak testy temperamentu i osobowości, odpowiadały na ważne potrzeby społeczne. Rozwój metod testowych w ocenie zdolności muzycznych dawał poczucie mierzalności predyspozycji do odniesienia sukcesu w dziedzinie muzycznego wykonawstwa.

Maria Manturzewska prowadziła zakrojone na szeroką skalę badania dzieci, które trafiały do szkół muzycznych. Ufała testom, ale zdawała sobie sprawę z ograniczonej trafności ich stosowania. A może zaobserwowała, że za ich pomocą nie sposób odkryć istotnych niuansów decydujących o powodzeniu artysty? Następnie zwróciła się w kierunku badań biograficznych. Potwierdzały one znaczenie udziału rodzica $\mathrm{w}$ kształceniu muzycznym dziecka dla jego późniejszych osiagnięć w dziedzinie wykonawstwa muzycznego. Czy czynniki osobowościowe, biograficzne i związane z edukacją to kompletny zestaw uwarunkowań powodzenia artystycznego w zawodzie muzyka? Być może interdyscyplinarne i wielowymiarowe badania rozwoju w ciagu życia zawodowych muzyków pozostawiały ważne kwestie trudne do uchwycenia? Z inicjatywy Marii Manturzewskiej powstał współredagowany przez Halinę Kotarską podręcznik Wybrane zagadnienia z psychologii muzyki (1990). Obejmuje on szeroki wachlarz tematów, przedstawiając psychologię muzyki jako bogaty i zróżnicowany obszar nauki.

Co najmniej od początku lat 80. Maria Manturzewska aktywnie udzielała się w Polskim Towarzystwie Psychologicznym i w Komitecie Nauk Psychologicznych PAN. Organizowała sympozja, dyskusje panelowe i konferencje. Działała także na arenie międzynarodowej jako członkini International Association of Empirical Aesthetics (IAEA). Animowała środowisko do wymiany doświadczeń badawczych. Uczestniczyła w konferencjach i zachęcała do tego swych uczniów i współpracowników.

Maria Manturzewska nawiązała kontakt z Johnem Sloboda, Alfem Gabrielssonem, Heinerem Gembrisem, Edwinem Gordonem, Davidem Hargreavesem, Helgą de la Motte, Rosamund Shuter i wieloma innymi badaczami zajmującymi się psychologią muzyki. Z niektórymi serdecznie się przyjaźniła. Czasem odwiedzali Instytut, a Manturzewska wizytowała ośrodki niemieckie. Tak liczne kontakty zagraniczne były wtedy w Polsce rzadkością, a dostęp do światowej literatury i umiejętność korzystania z niej miało wówczas niewielu. W 1990 roku w Radziejowicach odbyła się konferencja naukowa, w której na zaproszenie prof. Manturzewskiej udział wzięli najważniejsi ówcześni przedstawiciele psychologii muzyki.

W oczach ludzi Zachodu Maria Manturzewska uosabiała myśl Europy Środkowej i Wschodniej. Była oczytana, także w beletrystyce. Jej znajomość literatury europejskiej nie miała sobie równych. Brała udział w konferencjach, zabierała głos. To się podobało, zwracało uwagę. Miała wiele osobistych atutów. Była ceniona towarzysko dzięki erudycji i obyciu w świecie muzyki i humanistyki. Wieloletnia przyjaźń łączyła ją z prof. Andrzejem Rakowskim, kierownikiem Katedry Akustyki Muzycznej, rektorem Akademii Muzycznej w latach 80. Lubiła rozmawiać ze specjalistami. Ceniła prof. Marię Kielar-Turską i jej badania nad reprezentacją świata w umyśle dziecka. Bliska jej była powszechna dziś koncepcja rozwoju w ciagu życia. Badania biograficzne muzyków prowadziła w tym właśnie paradygmacie. 
Maria Manturzewska wysoko ceniła wspólny dorobek naukowy pracowników Katedry Psychologii Muzyki. Dbała, aby nie został zaprzepaszczony. Po likwidacji katedry, która była dla niej wielkim ciosem, zabiegała o to, by prace naukowe zostały zebrane i utrwalone w formie publikacji książkowej. Nie doczekała tego. Czy znajdą się środki i wola, by przynajmniej zarchiwizować zachowane materiały badawcze, co uchroniłoby je przed rozproszeniem i zaginięciem?

\section{NASTĘPCY. WSPÓLCZESNOŚĆ PSYCHOLOGII MUZYKI W POLSCE}

Badacze młodego pokolenia zwracają uwagę na stosowany wymiar pracy naukowej w dziedzinie psychologii muzyki. Dr Maria Chełkowska-Zacharewicz, psycholog i muzyk, adiunkt na Wydziale Nauk Społecznych Uniwersytetu Śląskiego, prowadzi badania z zakresu reakcji emocjonalnych na muzykę. Jest członkinią executive council w stowarzyszeniu European Society for the Cognitive Sciences of Music i reprezentantką na Polskę z ramienia jego zarządu. Wraz z dr Julią Kaleńską-Rodzaj współredagowała wydaną w 2020 roku pracę zbiorową Psychologia muzyki. Chełkowska-Zacharewicz mogłaby być wnuczką Manturzewskiej. Dotarła do niej już po ukończeniu studiów psychologicznych, w trakcie pracy nad doktoratem w 2012 roku. Uruchomiła fakultatywny kurs z zakresu psychologii muzyki na Uniwersytecie Śląskim, równocześnie planując i prowadząc swoje badania. Podczas gdy Manturzewska w swoich zainteresowaniach była mocno skoncentrowana na wykonawcy, Chełkowska-Zacharewicz rozpoczęła swoje badania od poznawczych i emocjonalnych aspektów odbioru muzyki. Pracuje również z muzykami nad ich przygotowaniem do występów i towarzyszącymi temu problemami.

Kontekst i dynamika życia muzyka zawsze znajdowały się w centrum zainteresowań Marii Manturzewskiej. Jej praca badawcza zainspirowała Marię Chełkowską-Zacharewicz do rozwijania metod wspierania muzyka na różnych etapach rozwoju. Aktualne projekty badawcze Chełkowskiej-Zacharewicz idą w kierunku pro- filaktyki zdrowia psychicznego u muzyków, co wcześniej propagowała prof. Manturzewska. Chełkowska-Zacharewicz zetknęła się z tym podejściem i sama również je praktykuje. Pracuje indywidualnie z muzykami oraz prowadzi przeznaczone dla nich warsztaty treningowe i rozwojowe, przede wszystkim w modelu elastyczności psychologicznej w terapii akceptacji i zaangażowania. Model ten podkreśla rolę umiejętności formułowania relacji z sytuacja, w której jednostka aktualnie się znajduje. Idealnie wpisuje się w potrzeby środowiska muzycznego, w którym umiejętności psychologicznych nie ćwiczy się w stopniu wystarczającym do obciążającego psychicznie zawodu. Chełkowska-Zacharewicz, podobnie jak Manturzewska, dostrzega potrzebę rozwijania poradnictwa psychologicznego i profilaktyki zdrowia psychicznego dla tej szczególnej grupy zawodowej.

Gdy w 2017 roku John Sloboda dowiedział się o zamknięciu Katedry Psychologii Muzyki w Akademii Medycznej i rozproszeniu badaczy na różne sposoby uprawiających psychologię muzyki, zaprosił Chełkowską-Zacharewicz do działalności w ESCOM. W 2018 roku zorganizowała ona konferencję „Psychomuzy”, w której udział wzięło około 100 osób. Nie było wśród nich prof. Manturzewskiej, ale całym sercem kibicowała ona swojej młodszej koleżance w roli moderatorki wymiany naukowej badaczy skupionych wokół odbiorców i twórców muzyki.

We wrześniu 2018 roku Chełkowska-Zacharewicz odwiedziła Marię Manturzewską. Pani profesor wyrażała głęboką troskę o rozwój psychologii muzyki, o badania, ludzi i o to, by ta dziedzina nie zniknęła, by się rozwijała. Wykazywała autentyczne zainteresowanie tematem. Nadal starała się być na bieżąco i deklarowała chęć stałego kontaktu. Było to ich jedyne spotkanie.

W opinii Chełkowskiej-Zacharewicz Maria Manturzewska świadomie wychodziła poza paradygmat eksperymentalnych badań naukowych, przyjmując za priorytet to, co w rozmowie z człowiekiem można uchwycić poza schematem. Manturzewska reprezentowała nurt psychologii podkreślający znaczenie cech względnie stałych, lecz pozostała otwarta także na postrzeganie zmian rozwojowych w ich kon- 
tekście oraz na czynniki modyfikujące ścieżkę rozwoju i przyczyniające się do zmiany prawdopodobieństwa powodzenia w zawodzie muzyka. Chełkowska-Zacharewicz przypuszcza, że gdyby Maria Manturzewska prowadziła swoje badania dzisiaj, najprawdopodobniej stosowałaby w nich właśnie podejście kontekstualne, kładące nacisk na dynamikę zmian i relacji pomiędzy nimi, które znajdują odzwierciedlenie w funkcjonowaniu jednostki i jej rozwoju.

\section{DYGRESJA. EDUKACJA MUZYCZNA DZISIAJ}

Psychologia muzyki to termin rozległy, wymagający uściślenia za każdym razem, gdy się go używa. Dźwięk, brzmienie, jego percepcja i doświadczanie, jak również wytwarzanie i warunki dostarczania go na żywo słuchaczom to zarówno kakofonia, jak i symfonia zagadnień badawczych wymagających często współpracy specjalistów z różnych dziedzin - audiologii, różnych specjalności medycznych, akustyki, psychologii, socjologii, pedagogiki, informatyki, muzykologii i wreszcie wykonawstwa muzycznego. Sa przykłady systematycznej i wieloletniej udanej współpracy. Właśnie taka istniała pod kierownictwem profesor Marii Manturzewskiej w Międzywydziałowej Katedrze Psychologii Muzyki. W historii polskiej psychologii widać jednak na ogół, że muzycy stronią od psychologów, psychologowie od pedagogów, a wszyscy chcieliby „mieć racje”". Konieczne jest zatem, aby szanując wzajemnie odrębność i specyfikę swych dziedzin, ich przedstawiciele nadal wypracowywali sposoby na twórczą i konstruktywną współpracę.

Mateusz Migut pamięta profesor Manturzewską z czasów, gdy będąc już na emeryturze, aktywnie brała udział w seminariach Katedry Psychologii Muzyki. Obserwowała, ale też zabierała głos. Sprawiała wrażenie, jakby chciała być na bieżąco i próbowała wyrobić sobie zdanie na każdy z poruszanych tematów. Starała się śledzić aktualne trendy w publikacjach. Była wyczulona na nowinki naukowe. Lubiła dowiadywać się od innych. Zachęcała do prezentowania pracy naukowej, czasem po- naglała, dawała sugestie. Jako pasjonatka charakteryzowała się pokorą intelektualną. Potrafiła z uznaniem mówić o czyjejś pracy, wyrażając szczere zaciekawienie.

Prof. Maria Manturzewska była w nauce postacią ważną i unikatową. Rozwinęła w Polsce dziedzinę psychologii muzyki, koncentrując się na kształceniu młodzieży szczególnie uzdolnionej w epoce, gdy edukacja muzyczna, podobnie jak aktywność sportowa, miała realizować cele społeczne i polityczne. Ponadprzeciętne osiągnięcia w dziedzinie wykonawstwa muzycznego jak zawsze przyciągały melomanów. Nie można jednak pominąć tego, że w naszej części świata akcentowano także przewagę krajów reprezentowanych przez wielkie muzyczne osobowości ponad innymi. Utalentowanych poszukiwano, kształcono i eksploatowano. Uzdolnione dziecko włączano w system kompleksowej edukacji muzycznej, widząc w nim przyszłego zawodowego muzyka. Dla Marii Manturzewskiej wybitność stanowiła główny obiekt naukowych zainteresowań i podstawowy cel edukacji artystycznej. Profesor Manturzewska nie zajmowała się edukacją muzyczną w trybie ekstensywnym ani o zasięgu powszechnym. Uważała szkołę muzyczną za kuźnię profesjonalistów. W badaniach poszukiwała wskazówek dla psychologów i pedagogów na temat tego, kiedy zaczynać kształcenie muzyczne, od kiedy stymulować dzieci muzycznie, tak by było to najbardziej efektywne dla przyszłych osiagnięć. Uczestniczyła w opracowaniu modelu kształcenia nauczycieli przedmiotów artystycznych. Profil jej naukowych dociekań był spójny z opisanym tu schematem edukacji muzycznej skupionej na przygotowaniu ucznia do zawodu muzyka. Choć Maria Manturzewska prowadziła badania odnośnie do preferencji muzycznych młodzieży, zagadnienia dotyczące muzyki jako dziedziny rozwoju człowieka, pasji bez zobowiązań zawodowych, pozostawały na dalszym planie, a wręcz poza obszarem jej zainteresowań.

W tym miejscu można się pokusić o słowo refleksji nad dzisiejszymi celami akulturacji i edukacji muzycznej. Jest to zarazem zagadnienie, które dotyczy miejsca muzyki w życiu całych pokoleń, zainteresowania muzyką jako dziedziną sztuki oraz zapotrzebowania zarów- 
no na czynne uprawianie muzyki, jak i na jej słuchanie. W drugiej połowie XX wieku edukacja muzyczna w Polsce przybrała charakter intensywny: edukowano przede wszystkim wybrane jednostki o kierunkowych uzdolnieniach. Metody testowe odpowiadały na ówczesne zapotrzebowanie społeczne: dzięki nim planowano wyselekcjonować osoby przejawiające uzdolnienia, które miałyby predyspozycje do zawodu muzyka. Z dzisiejszego punktu widzenia tak rozumiane cele kształcenia muzycznego w pewnej mierze je uprzedmiatawiają. Dziecko zdolne już od wczesnych klas szkoły podstawowej jest poddawane intensywnemu treningowi umiejętności gry na instrumencie. Program zakłada rozwijanie sprawności technicznej i muzykalności. Przyjemność z muzykowania jest odsuwana na dalszy plan, podczas gdy praktyka solowych występów i obligatoryjność ,,zaliczania" ustalonego programu nasila stres i obniża motywację do nauki. System średniego i wyższego kształcenia muzyków tym bardziej nastawiony jest na specjalizację, wirtuozerię i granie solowe dostępne później nielicznym. W konsekwencji tak rozumianej edukacji artystycznej muzycy w trakcie kształcenia przypominają zawodowych sportowców, którym po zakończeniu kariery pozostaje nadwątlony organizm oraz brak chęci do dalszej aktywności sportowej. Wielu absolwentów liceów czy akademii muzycznych zaraz po ukończeniu edukacji na poziomie średnim czy wyższym ,wiesza instrument na kołku" i szuka innej drogi zawodowej. Tematyka ta, odległa od zainteresowań badawczych prof. Manturzewskiej, domaga się rozważenia na nowo, a być może również przeformułowania celów, jakie edukacja młodzieży muzycznie uzdolnionej powinna realizować. Konieczne w tej dziedzinie odświeżenie i otwarcie powinny być rezultatem wnikliwej debaty osób prowadzących naukowe badania w dziedzinie psychologii muzyki, pedagogów muzycznych i samych uczniów.

Maria Chełkowska-Zacharewicz i dr Andrzej Białkowski, pedagog z Uniwersytetu Marii Curie-Skłodowskiej w Lublinie, dostrzegaja konieczność przeformułowania powszechnego kształcenia muzycznego w kierunku rozwijania zainteresowań i wspierania pasji muzycznych w przeciwieństwie do narzucania obowiązkowych praktyk muzycznych i koncentracji na efektach ćwiczeń. Mateusz Migut, współtwórca projektu „Muzyka jest dla wszystkich”, podkreśla wagę krzewienia umuzykalnienia jako powszechnej formy akulturacji. Szerzenie kultury muzycznej to ważny wątek kształcenia muzycznego, do którego w edukacji muzycznej na poziomie wyższym brakuje determinacji. To temat związany z rozwojem zainteresowań, przyjemnością i zdrowiem, który mógłby się okazać atrakcyjny zarówno dla praktyków, jak i dla badaczy. Byłaby to nowatorska kontynuacja pracy prof. Marii Manturzewskiej, dostosowana do potrzeb i celów współczesnej młodzieży, rozwijająca jej talenty i poszerzająca możliwości spełniania się w muzycznych interakcjach.

\section{PODSUMOWANIE. SPOJRZENIE W PRZYSZLOŚĆ}

Z zebranych wspomnień wyłania się obraz prof. Marii Manturzewskiej jako osoby wybitnej, niezwykłej, niezależnej, o silnej osobowości i motywacji do robienia rzeczy ciekawych z rozmachem i dynamizmem. Równocześnie obrane przez nią cele działalności naukowej mają charakter jednostronny i niejako podtrzymują ściśle elitarny sposób rozumienia aktywności muzycznej człowieka, a co za tym idzie edukacji muzycznej. Współcześnie bardziej adekwatne wydaje się spojrzenie na akulturację i edukację muzyczną w sposób egalitarny. Kontakt człowieka z muzyką otwiera go na złożony świat dźwięków, poszerzając jego postrzeganie rzeczywistości. Zawłaszczenie tego obszaru przez szkołę i wciągnięcie go na listę licznych obowiązków ucznia spłyca i zniechęca do podejmowania aktywności muzycznej. System, w którym utalentowane dziecko dostaje się w tryby edukacyjnej maszyny i często jest pozbawiane możliwości decydowania o swoim muzycznym losie, stanowi antytezę sztuki, która ma uwrażliwiać i stanowić dziedzinę samorealizacji. Należy się zastanowić, czy stawiając głównie na efekty nauczania, w porównaniu z samym procesem nauki, nie zatraca się delikatnej materii edukacji artystycznej. A może 
intensywny i ekstensywny profil nauczania muzyki mogłyby istnieć równolegle?

W rozwoju ludzkości muzyka jako środek wyrazu, sposób ekspresji tego, co trudne do zwerbalizowania, ma swoją długą historię i ważne miejsce. Celem edukacji muzycznej powinno być zapewnienie dzieciom i młodzieży pogłębionego kontaktu z różnymi formami sztuki muzycznej oraz ułatwienie im świadomego wyboru obszarów, w których chciałyby się rozwijać i aktualizować własne potencjały twórcze. Podejście to łączy się z budowaniem wrażliwości zmysłowej i emocjonalnej oraz rozwijaniem wyobraźni. Zajęcia $\mathrm{w}$ ramach edukacji muzycznej to dla wielu podstawowa forma kontaktu ze sztuką. Stanowią punkt wyjścia do formowania się motywacji i gustów, które znajdują wyraz w późniejszych zainteresowaniach estetycznych. Wprowadzanie dzieci i młodzieży w świat muzyki wymaga od nauczyciela stosownego wykształcenia i motywacji do dzielenia się swymi muzycznymi pasjami. Zadaniem nauczyciela muzyki byłoby więc zapoznanie ucznia z możliwościami ekspresyjnymi muzyki, z zachowaniem ostrożności co do formułowania ocen, jakiej muzyki słuchać warto, a jakiej nie. Andrzej Białkowski podkreśla, że podejście to, choć nienowe, w Polsce nigdy nie było szerzej obecne. Edukacja muzyczna kojarzy nam się najczęściej z tym, co systemowe, co dzieje się na lekcjach muzyki w szkołach, albo z intensywnym kształceniem zawodowym nastawionym na formowanie przyszłych zawodowych muzyków. Tymczasem kontekstem rozwijania muzycznych pasji są także inicjatywy nieformalne, którym patronować mogą samorządy, stowarzyszenia twórcze, ogniska pracy pozaszkolnej, kluby itp. Trzeba też pamiętać, że środowisko muzyczne skutecznie ,zaopiekuje się” osobami zainteresowanymi muzyką. Wtedy można liczyć na chętne muzykowanie, pełne sale koncertowe, a być może nawet złagodzenie obyczajów.

Muzyka jako sposób ekspresji i forma realizacji pasji twórczej to obszar, który domaga się poszerzania dla ludzi w różnym wieku. Dostępność tak prowadzonej edukacji muzycznej ma szansę poskutkować podwyższeniem kultury muzycznej społeczeństwa. Taki nurt warto rozwijać. Prof. Maria Manturzewska na pewno chciałaby być w tym temacie na bieżąco. 